INTERNATIONAL JOURNAL OF MULTidisciplinARY RESEARCH AND ANALYSis

ISSN(print): 2643-9840, ISSN(online): 2643-9875

Volume 04 Issue 11 November 2021

DOI: 10.47191/ijmra/v4-i11-14, Impact Factor: 6.072

Page No.- 1583-1587

\title{
Strategy for Sustainable Tami River Management as One of the Priority Watersheds in Indonesia
}

\author{
Alfred Alfonso Antoh \\ Biology education study program, Department of Mathematics and Natural Sciences Education, Faculty of Teacher Training and \\ Education, Cenderawasih University \\ Jalan Raya Sentani, Abepura 99351, Jayapura, Papua Province, Indonesia
}

\begin{abstract}
Rivers and their natural potential are important and useful to support the welfare of people's lives. The Tami River which is located in Keerom Regency is included in the management priority because it is a river located in the border area of Indonesia and Papua New Guinea. The Tami river ecosystem stores various kinds of biodiversity that are important to support human life. The research objective is to develop a strategy for managing the Tami river in a sustainable manner by considering it as a priority river within national borders. The results of the research on the Tami river have high biodiversity potential. More than 27 species from 21 plant families were found and 40 species from 28 tree families were also found around the river area. In addition to flora, there is also the potential for fauna of various types of mammals, Avivauna, Heterofauna and various types of birds around the Tami river. The potential of the Tami river can be developed to produce energy for power generation. The Tami river development strategy requires planned and synergized cooperation between parties so that it can be sustainable and provide benefits to the surrounding community.
\end{abstract}

KEYWORDS: Tami river management, Biodiversity Potential, Management strategy

\section{INTRODUCTION}

Watershed (DAS) or is an area that comes from rain that enters the river in the form of surface runoff, underground water and raindrops that fall directly on the river surface. The water will certainly flow through the boundaries of the ecological area without taking into account the administrative boundaries of a government area, either Regency/City or Province and State. Tami watershed is one of the priority watersheds in Indonesia, which is located in Papua Province. In addition, the management of the Tami river is also inseparable from the management of the Cycloop mountain nature reserve conservation area which is the upstream part (Antoh \& Raunsay, 2019). Based on the Decree of the Minister of Forestry Number SK 328/Menhut-II/2009 regarding the determination of priority watersheds as stated in the Medium Term Development Plan (RPJM) 2010-2014. Tami watershed has an area of 4,750 $\mathrm{Km} 2$ or an area of 475,000 $\mathrm{Ha}$. Tami watershed is a cross-regency and city watershed as well as a cross-country watershed where $70 \%$ is in the territory of the Republic of Indonesia and about 30\% in Papua New Guinea (PNG). Furthermore, more than $70 \%$ are also in the Kerom district and $13 \%$ in the Jayapura City area and only about $5 \%$ in Jayapura District, Papua Province.

The population growth rate in the last 5 (five) years is quite high so that the impact on land clearing for the benefit of new settlements and the expansion of new agricultural areas can certainly pose a serious threat to the area. For this reason, the efficient use of natural resources is the key to being sustainable (Antoh et al. 2018). Antoh et al (2019) in another study explained that the yard landscape approach can be an alternative in managing the Tami river for people who live and live around it. This condition is also exacerbated by the diversion of forest functions to become oil palm plantation areas, which continues to increase from year to year so that it often causes flooding effects to residential areas around the watershed. Professional watershed management by involving many parties and many interests needs to be considered together, so that through this study, we can put forward practical matters that are important to become the basis and main priority in future watershed management.

Some of the problems that can be identified and pose a threat and cause a fairly high impact and danger of damage in the Tami watershed area are human activities such as; there are still community activities carrying out shifting cultivation, deforestation activities and land clearing for settlements that are not appropriate. Besides that, there are also natural causes that 


\section{Strategy for Sustainable Tami River Management as One of the Priority Watersheds in Indonesia}

can cause damage to the Tami watershed such as: high rainfall conditions, sloping topography conditions, unstable soil types and the morphology of the river itself which can cause natural damage to the Tami watershed itself.

To develop a management strategy for the Tami watershed in Papua Province as one of the priority watersheds in Indonesia based on the potential of its biological natural resources. Proper management of the Tami watershed with a comprehensive and integrated approach is directed at all stakeholders, in particular, the community around the Tami watershed and the government, both provincial and district and city, and even countries with broad interests can obtain maximum benefits from the management of the Tami watershed and can also become a source of income. a new model that can be developed as an example in priority watershed management in Indonesia.

\section{MATERIALS AND METHODS}

This research was carried out for approximately two months and took place in the Tami watershed, Keerom district, Papua Province, Indonesia (Figure 1).

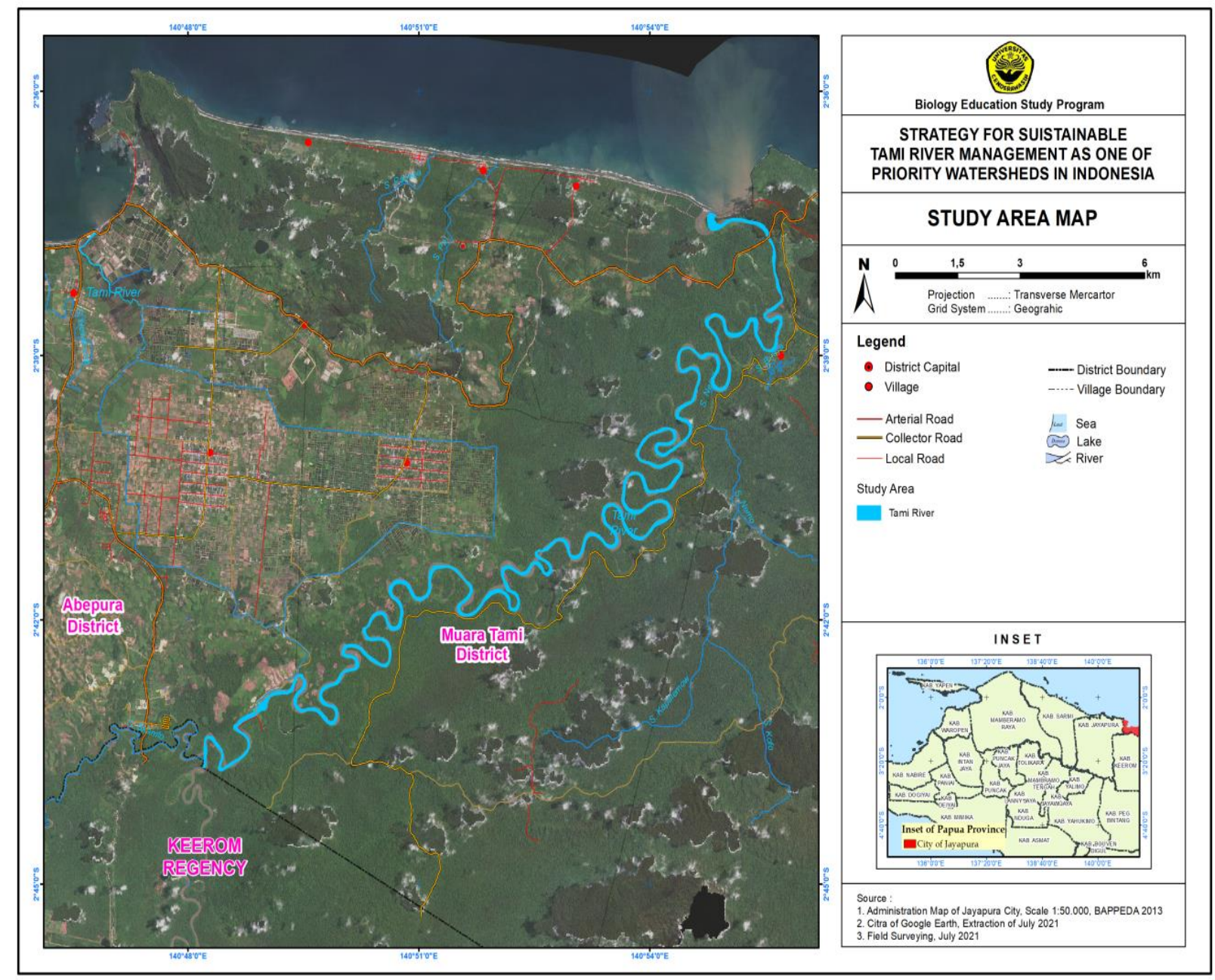

Figure 1. The research location for the Tami River Basin, Keerom Regency, Papua Province, Indonesia

To support this research, the tools and materials needed include: stationery, voice recorder, digital camera, GPS and questionnaire sheet. This research was conducted by purposive sampling technique. Furthermore, in-depth interviews were conducted with respondents who have ties to the Tami river, such as: the forestry service, the river hall, the agriculture office, community leaders, religious leaders, and non-governmental organizations. Furthermore, it has also carried out on documents that have been produced both in the local government of Keerom Regency, Jayapura City, Jayapura Regency and also documents in Papua Province which are relevant to the main tasks and functions of Tami river management. The data collected was then analyzed descriptively. 


\section{Strategy for Sustainable Tami River Management as One of the Priority Watersheds in Indonesia}

\section{SPACE UTILIZATION CONFLICT}

The Tami watershed, which is mostly located in the Kerom district, is a flat and wide area which is very suitable for the development of the agricultural sector. By the central government, this area is one of the main areas for resettlement for transmigrants from Java, Bali and NTT. Existing community activities certainly further develop the agricultural sector to support regional development. On the other hand, although the condition of the Tami watershed, which is still very much dominated by primary and secondary forests, or forest area is still around $85.97 \%$ or around 386,002 hectares in 2008 . However, with the increase in population, new land clearing activities continue to occur around the area. the Tami watershed area, thus placing greater pressure on the watershed. Extensive land use can lead to increased critical land and decreased land productivity (Arsyad.S \& Ernan R., 2008). For example: Oil palm cultivation activities have converted more than 8.27 percent of the area around the existing watershed area. The waters of the Tami river are currently not managed by the community. Another study explains that ecosystem management for aquaculture activities will someday be the community's choice (Pregiwati et al. 2015). This condition will continue to develop along with the opening of road access as well as bridge facilities and other supporting facilities. High land clearing can encourage damage to the surface layer of the soil (Arsyad S., 2006). Percentage of land use shows a significant change (Table 1).

Table 1. Types and Areas of Land Use in the Tami Watershed in 2002 and 2008

\begin{tabular}{|l|l|l|l|l|l|}
\hline \multirow{2}{*}{ Numb. } & Type of Land Use & Year 2002 & \multicolumn{2}{l|}{ Year 2008 } \\
\cline { 3 - 6 } & & hectares & $\begin{array}{l}\text { \% watershed } \\
\text { area }\end{array}$ & hectares & $\begin{array}{l}\text { watershed } \\
\text { area }\end{array}$ \\
\hline 1. & watershed & 9.383 & 2,09 & 10.333 & 2,30 \\
\hline 2. & Forest (Primary+Secondary) & 396.308 & 88,27 & 386.002 & 85,97 \\
\hline 3. & Open field & 12.751 & 2,84 & 9.978 & 2,22 \\
\hline 4. & Settlement & 2.873 & 0,64 & 5.530 & 1,23 \\
\hline 5. & Oil palm plantation & 9.473 & 2,11 & 27.585 & 6,14 \\
\hline 6. & Moor & 17.914 & 3,99 & 8.477 & 1,89 \\
\hline 7. & Ricefield & 269 & 0,06 & 1.066 & 0,24 \\
\hline & Amount & 448.972 & 100 & 448.972 & 100 \\
\hline
\end{tabular}

Source: Results of Digital Processing of Landsat 7 TM imagery covering 15-06-2002 and Aster Image in 2006, Alos Image in 2007 and field verification in 2008

Direct access that also needs to be taken into account is the plan to build a hydroelectric power plant in the Tami watershed which is an important issue that is quite interesting as well as an irrigation development plan to support the development of the agricultural sector. When all parties enter with different interest backgrounds, it will certainly cause a time bomb, conflict in the future in the use of land and the Tami watershed will be increasingly threatened. All stakeholders in the Tami watershed will position themselves as important in taking the greatest benefits. Preventive actions to prevent conflicts between institutions internally and externally need to be avoided as early as possible in preparing a careful and integrated Tami Watershed Management Plan.

\section{POTENTIAL FOR BIODIVERSITY IN THE TAMI. WATERSHED AREA}

The role of the river has a great contribution to humans in and around the river, for example providing water, transportation, a place to find food sources and media to dispose of waste (Irianto, 2009). Another portrait that certainly has not been considered well is the condition of biodiversity around the Tami river watershed. More than 27 species from 21 plant families were found and 40 species from 28 tree families were also found around the river area. In addition to flora, there is also the potential for fauna of various types of mammals, Avivauna, Heterofauna and various types of birds around the Tami watershed. Biodiversity has an important role in protecting the environment and can be used to meet the needs of human life in the vicinity (Jones et al. 2018). The results of the study show that the species found are native to Papua. Portrait of the Tami river when the river water conditions are receding (Figure 1). 


\section{Strategy for Sustainable Tami River Management as One of the Priority Watersheds in Indonesia}

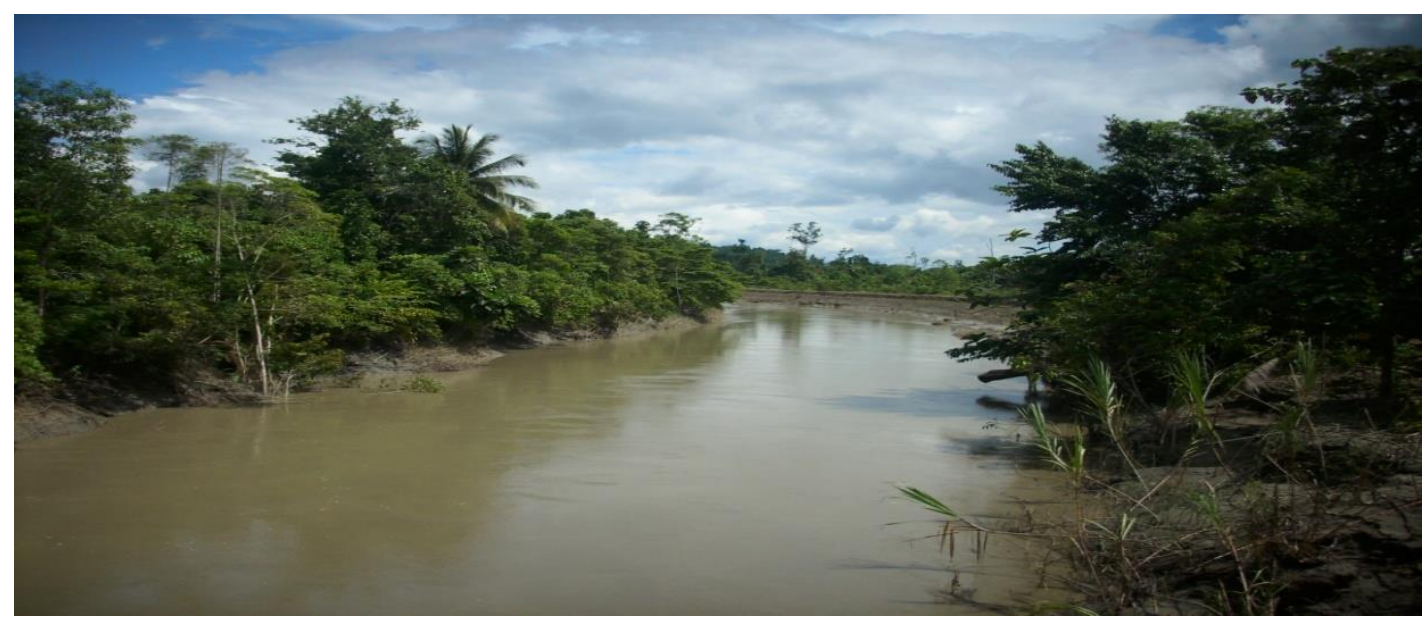

Figure 1. Photo: Tami Watershed, Papua as one of the Priority Watersheds in Indonesia

\section{SYNERGISTIC COOPERATION OF ALL PARTIES}

The development of the Tami watershed should be able to synergize all existing stakeholders or stakeholders. For example: Forestry, Plantation and Agriculture Service, Public Works, Mining, Regional Environment Agency, Regional Planning and Development Agency, Universities, NGOs, Customary and Religious Leaders as well as Ulayat Rights owners in their respective areas need to sit down together to draw up a management Grand Design Tami watershed. The involvement of all these parties will have a shared responsibility and be involved continuously in guarding the management of the Tami watershed in a better direction. The community certainly receives benefits in the development of the Tami river ecosystem. Another study conducted in the Amazon river explains that community involvement in the management of environmental services can improve community welfare for generations (Pinto et al. 2018). The results of the formulation of ideas need to be determined in the form of a mutual agreement so that they can avoid conflicts that occur in the future in managing the Tami watershed in Papua Province.

\section{SYNERGISTIC COOPERATION OF ALL PARTIES}

The development of the Tami watershed should be able to synergize all existing stakeholders or stakeholders. For example: Forestry, Plantation and Agriculture Service, Public Works, Mining, Regional Environment Agency, Regional Planning and Development Agency, Universities, NGOs, Customary and Religious Leaders as well as Ulayat Rights owners in their respective areas need to sit down together to draw up a management Grand Design Tami watershed. The involvement of all these parties will have a shared responsibility and be involved continuously in guarding the management of the Tami watershed in a better direction. The community certainly receives benefits in the development of the Tami river ecosystem. Another study conducted in the Amazon river explains that community involvement in the management of environmental services can improve community welfare for generations (Pinto et al. 2018). The results of the formulation of ideas need to be determined in the form of a mutual agreement so that they can avoid conflicts that occur in the future in managing the Tami watershed in Papua Province.

\section{TAMI WATERSHED MANAGEMENT STRATEGY}

Building an idea and a shared commitment in managing land and water resources specifically for the Tami watershed requires a lot of time, effort and money. The concrete step to manage the Tami watershed is to build a forum, namely: the Tami Watershed Forum. This forum has been established in Papua which is able to build partnerships with district and city governments in Papua province where the forum has collaborated with Cenderawasih University as one of the first local universities to help provide input and ideas through academic studies in order to be able to encourage a form of a new strategy that is able to involve many parties in managing the Tami watershed in a planned manner. The decision-making process is carried out by using the Hierarchical Process Analysis (AHP) approach. The AHP process carried out aims to select and establish an appropriate and sustainable management model (Lepetu., 2012). The results of the study explained that by the end of 2011, the maximum effort had been achieved by the Tami Watershed Forum, which had compiled a Grand Design Strategy to manage the Tami watershed. This result will be followed up with outreach activities addressed to all parties, including the community around the Tami watershed area, to continue to manage land in the right area according to its designation. Community land management can be done on a micro basis with a yard management model for food adequacy needs and still pay attention to environmental sustainability aspects (Mohri., 2013). Example: a protected forest area, it is hoped that it will no longer be opened for the opening of new settlements or new agricultural 


\section{Strategy for Sustainable Tami River Management as One of the Priority Watersheds in Indonesia}

land or mining activities, excavation $\mathrm{C}$ and other activities according to the results of a mutual agreement. Other studies explain that reduced land use activities can reduce damage to the environment (Widiatmaka., 2007).

\section{CONCLUSION}

Tami watershed management needs to be carried out in a planned and synergistic manner with all stakeholders to be involved together collectively and actively. It is necessary to carry out socialization activities on the benefits of Tami watershed management to the surrounding community according to academic studies in order to preserve nature and manage the Tami watershed in a sustainable and sustainable manner. With the preservation of the Tami watershed, it is able to support the existing ecosystem and maintain the balance of the environment and its habitat. Finally, it is hoped that it will be able to avoid conflicts of interest in the use of the Tami watershed and land in order to improve the welfare of the community in a better direction.

\section{ACKNOWLEDGEMENTS}

We would like to thank the Ministry of Forestry of the Republic of Indonesia for our involvement in the research to develop a plan document for the management of the Tami watershed as one of the priority watersheds in Indonesia.

\section{REFERENCES}

1) Antoh A., Raunsay EK. 2019. Diversity of Yard Plants in the Buffer Zone of the Cycloop Nature Reserve, Jayapura City, Papua Province, Indonesia. AAB Bioflux;11 (3):157-161.

2) Antoh A., Nurhayati., Chozin M. A., Arifin H. S. 2019. Short communication: Agricultural biodiversity and economic productivity of the yards in Arguni Bawah, Kaimana District, West Papua Province, Indonesia. 20 (4): 1020-1026.

3) Antoh. A., Nurhayati., Chozin MA, Arifin HS. 2018. Penilaian keberlanjutan masyarakat di Distrik Arguni Bawah, Kabupaten Kaimana, Provinsi Papua Barat. Jurnal Ilmu Lingkungan. 16 (2): 113-119.

4) Arsyad.S., 2006. Konservasi Tanah dan Air. Penerbit IPB Press. Bogor

5) Arsyad.S \& Ernan R., 2008. Penyelematan Tanah, Air dan Lingkungan. Penerbit Yayasan Obor Indonesia. Jakarta

6) Jones L, Alice. M., Jane H, Gina M., Allan P, Michael C., 2018. Valuing Improvements Due to Controls on Atmospheric Nitrogen Pollution. Ecological Economics, 152, (358-366).

7) Lepetu JP. 2012. The Use of Analytic Hierarchy Process (AHP) for Stakeholder Preference Analysis: A case Study from Kasane Forest Reserve, Botswana. Journal of Soil Science and Environmental Management, 3(10), 237-251.

8) Mohri H., Shruti L., Osamu S., Anparasan M., Nimal G, Irham, Hoang VT, Gamni H., Kazuhiko T., Srikantha H 2013. Assessment of Ecosystem services in Homegardens Systems in Indonesia, Sri Lanka, and Vietnam. Ecosystem Services. 5:124-136.

9) Irianto.G., 2009. Pengelolaan Sumberdaya Lahan dan Air. Strategi Pendekatan dan Pendayagunaannya. Badan Penelitian dan Pengembangan Pertanian. Penerbit Papas Sinanti. Jakarta

10) Pinto HNA., Joseph EH., Peter N., Rafael FB. (2018). Economic Impacts of Payments for Environment Services on Livelihoods of Agro-Extractivist Communities in the Brazilian Amazon. Ecological Economic, 152,378-388.

11) Widiatmaka.S.H., 2007. Evaluasi Kesesuaian Lahan dan Perencanaan Tataguna Lahan. Jakarta 